\title{
Genetic Variant Severe Acute Respiratory Syndrome Coronavirus 2 Isolates in Thailand
}

\author{
Beuy Joob $^{1 *}$ (D) and Viroj Wiwanitkit ${ }^{2}$ (D) \\ ${ }^{1}$ Department of Sanitation, Medical Academic Center, Bangkok, Thailand. \\ ${ }^{2}$ Honorary Professor, Dr DY Patil University, Pune - 412 105, India.
}

Dear Editor,

Severe acute respiratory syndrome coronavirus 2 (SARCoV2) is a new emerging coronavirus that causes COVID-19. COVID-19 is a pandemic and attacks more than 200 countries around the world. Within 4 months, more than millions of world populations are infected. Due to the rapid spreading, an important consideration in clinical microbiology is the possible genetic variation of the new virus ${ }^{1}$. Here, the authors would like to share observations from Thailand, the second country that the COVID-19 occurs in global pandemic timeline ${ }^{2}$.

From PubMed search, there are 2 data on nucleotides of SARCoV2) isolates in Thailand (Accession: MN970004.1 and Accession: MN970003.1). The data are on "Severe acute respiratory syndrome coronavirus 2 isolate SI200121-SP orf1ab polyprotein, RdRP region, (orf1ab) gene" The 2 sequences are recorded in the same month of February 2020. From alignment by bioinformatics analysis tool LALIGN ${ }^{3}$, there is no difference of the two sequences. This can confirm that there is no change of genetic composition of virus in our setting. This might be an explanation for the non-serous situation of COVID-19 outbreak in Thailand.

The molecular study is an important tool in surveillance of new emerging virus infection. In conclusion, no difference of studied isolate is detected. This means there is no mutation in our setting which result in no serious change of clinical features of the disease. Nevertheless, since it is not yet the end of outbreak, further closed monitoring of genetic component is recommended. The surveillance for molecular epidemiology is recommended for any country affected by COVID-19.

\footnotetext{
*Correspondence: beuyjoob@hotmail.com
}

(Received: May 01, 2020; accepted: May 07, 2020)

Citation: Joob B, Wiwanitkit V. Genetic Variant Severe Acute Respiratory Syndrome Coronavirus 2 Isolates in Thailand. J Pure Appl Microbiol. 2020;14(suppl 1):693-694. doi: 10.22207/JPAM.14.SPL1.01

(C) The Author(s) 2020. Open Access. This article is distributed under the terms of the Creative Commons Attribution 4.0 International License which permits unrestricted use, sharing, distribution, and reproduction in any medium, provided you give appropriate credit to the original author(s) and the source, provide a link to the Creative Commons license, and indicate if changes were made. 


\section{ACKNOWLEDGMENTS}

None.

\section{CONFLICT OF INTEREST}

The listed author(s) declare no conflict of interest in any capacity, including competing or financial.

\section{AUTHORS' CONTRIBUTION}

All listed author(s) have made a substantial, direct and intellectual contribution to the work, and approved it for publication.

\section{REFERENCES}

1. Bajaj A, Purohit HJ. Understanding SARS-CoV-2: Genetic Diversity, Transmission and Cure in Human. Indian J Microbiol. 2020:1-4. doi: 10.1007/s12088-020-008694.

2. Yasri S, Wiwanitkit V. Editorial: Wuhan coronavirus outbreak and imported case. Adv Trop Med Pub Health Int. 2019;9:1-2.

3. Biro JC, Biro JM. The BlastNP: a novel, sensitive sequence similarity searching method using overlappingly translated sequences. Conf Proc IEEE Eng Med Biol Soc. 2004;2004:2777-80. 